\title{
ANALYZING THE DETERMINANTS OF NON-FARM INCOME DIVERSIFICATION OF FARM HOUSEHOLDS IN PESHAWAR DISTRICT OF PAKISTAN
}

\author{
Nazish KANWAL ${ }^{1}$, Muhammad Ammad KHAN ${ }^{2}$, Zhihao ZHENG ${ }^{3}$
}

DOI: 10.1515/tjeb-2016-0003

The agricultural sector in Pakistan is not well-established to provide full employment opportunities and sufficient income for needed living standard to the rural population. Stagnant agricultural productivity and low returns in farming have led rural residents to look for alternative livelihoods, especially non-farm employment. With this background, the present study is an endeavor to empirically determine the factors of non-farm income diversification of rural farm households in Peshawar district of Pakistan. The study was undertaken in four villages and data was amassed from 196 small farming households by using the multi-stage sampling technique. The data were analyzed using the descriptive statistical measures, the mean of income shares approach and the ordinary least squares regression analysis. The results indicate that in all the selected villages, the pattern of non-farm employment was more or less the same; however, the income from non-farm employment activities had an important contribution towards incrementing the absolute income of farm households. Non-farm income diversification is hence crucial for sustaining livelihoods and an integral dimension for invigorating rural economies. Therefore, the study recommends the promotion of non-farm employment as a good strategy for supplementing the income of small farmers without shifting attention from agriculture.

Keywords: $\quad$ Income diversification, Farm income, Non-farm income, Peshawar district, Pakistan.

JEL Classification: J3, R2, R23, Q1.

\footnotetext{
${ }^{1}$ Post-graduate student, Department of Agricultural Economics and Management, China, Agricultural University, Beijing, China.

${ }^{2}$ PhD Candidate, Department of Development Studies, China Agricultural University, Beijing, China

${ }^{3}$ Professor PhD, College of Economics and Management, China Agricultural University, Beijing, China
} 
Kanwal N., Khan M.A., Zheng Z. (2016).

\section{Introduction}

About 70 percent of the world's very poor people are rural (IFAD, 2011). Empirical evidence from a variety of literature suggests that poor rural households engage in multiple activities and rely on diversified income portfolios. In Pakistan, poverty is also a predominantly rural phenomenon as 80 percent of the poor live in rural areas (Maqbool, 2014) and most of them depend on agriculture for their livelihoods (PES, 2013-14). However, stagnant agricultural productivity and low returns in farming have led rural residents to look for alternative or supplemental income opportunities, primarily though non-farm employment. Actually, farming as a livelihood activity is associated with immense risks (climatic, pest and diseases, price, policy etc.). This phenomenon is more severe in Pakistan where appropriate lasting mitigation solutions have yielded average results. Farm households (households who engage in the production of crops and livestock) have increasingly sought means of escaping from the detrimental consequences of poverty by inclining to diversification of their activities; within and outside the farm sector. This is to primarily address their income and food security shortfalls (Barrett \& Reardon, 2000; Korir et al., 2005). Diversification therefore supports farm households to accumulate income for farm expansion engagement in non-farm businesses (Dimova \& Sen, 2010; Lay \& Schuler, 2008) and to solve immediate household needs (food, shelter, health care, payment of school fees etc.).

Ellis (2000) defined livelihood diversification as a process by which rural households construct an increasingly diverse portfolio of activities and assets in order to survive and improve their standard of living. Therefore, an analysis of the diversification concept has been assessed empirically from the asset, income or activity viewpoints. Asset measurement is deemed arduous and sometimes crudely estimated due to the poor development of the asset market (Barrett \& Reardon, 2000). Drawing on Minot et al. (2006), Ronning \& Koveried (2006), this study defines income diversification as "a situation where farm households rely on income from multiple sources; both farm and non-farm". Income diversification is commonly specified in conformity with the standard practice of national accounting and macro input/output table construction where separation is made among sectorial (agriculture and non-agriculture), functional (wage and self-employment) and spatial (migration influences) classifications of diversification. In this study, we follow the classification proposed by Barrett et al. (2001) according to sectors and functions. However, spatial classification was not distinguished here because there is not a single household in the sample where income from migrated household members is relevant. All income derived is therefore classified as local. More specifically, we describe the income activities of rural farm households and examine the determinants of nonfarm income diversification.

DE GRUYTER OPEN
Timisoara Journal of Economics and Business | ISSN: 2286-0991 | www.tjeb.ro Year 2016 | Volume 9 | Issue 1 | Pages: $33-48$ 
Kanwal N., Khan M.A., Zheng Z. (2016).

In Pakistan, rural farm households are often motivated to either participate in non-farm employment activities by pull or push factors. Households that are motivated by pull factors are those attracted by relatively higher returns from non-farm activities than the farming sector. Their decision to participate in non-farm work is principally to increase their earnings and not on the intention of risk reduction as opposed to households whose decision to diversify is due to push factors (risk aversion). This creates opportunities to choose activities that generate high returns. On the other hand, households that are motivated by push factors prioritize their survival rather than looking for better earnings. According to Reardon (1998), households who strive to manage their income and consumption uncertainties engaged in low return activities or activities that have negative correlation with farming sectors. Therefore, separately identifying the motivation behind the decision of the household to participate in non-farm employment activities is central for sound policy decision making.

The rural non-farm sector in Pakistan is a heterogeneous sector covering a wide spectrum of activities. The pursuit of this diversification leads one to explore the potentials of the whole range of non-farm activities (Ahmed, 2012). In Pakistan, non-farm employment may take all of three forms-- temporary, seasonal and permanent. The temporary employment includes; wage labor, exchange labor and part time activity, while seasonal skilled and semi-skilled jobs are carpentry, brick laying, blacksmith, employment in public and private sectors. It also includes self-employment i.e., retailers, wholesalers, rice mill owners, bus operators, and private entrepreneurs. However, permanent non-farm includes government employees, earnings from private sectors and other certain non-farm wages.

Agricultural sector in Pakistan is unfortunately not well-established to provide full employment opportunities and income sufficient for providing satisfactory living standard to the rural population. In almost all regions of the country, the poor are often marginal farmers or land-less laborers whose main source of income is usually the rural non-farm sector (Chaudhry et al., 2006). The development of various non-farm employment activities offers great potential for creating additional rural jobs and hence stimulates further economic growth of rural areas. The agricultural ministry has instead focused on farming and the industry ministry has focused on manufacturing, since little attention is given to the role and development of non-farm employment sector in the country. Non-farm sector is of great interest to developing rural economies for its productive and employment effects. Despite the recent increase in the literature on-farm/non-farm linkages, there has been no significant systematic study conducted on marginal areas in Pakistan, particularly in Khyber Pakhtunkhwa province. Most studies concentrate on dynamic agriculture, where cash crops are widely grown, while this study is to review the present situation of non-farm employment in rural areas of Peshawar district of Khyber Pakhtunkhwa province and identify major issues as well as suggesting measures for promoting rural non-farm employment activities. More specifically, this study is to assess and investigate the factors contributing to non-farm sector in Peshawar district. Results are 
Kanwal N., Khan M.A., Zheng Z. (2016).

expected to inform government agencies, NGOs and policy makers about the development and constraints of the rural non-farm sector, its link to the farming sector and its importance for the rural development policy. It is hoped that the results of this study will serve as a useful reference for further research on the subject.

In view of the growing importance of non-farm activities in the rural economy, this study explicitly seeks to: identify the sources of income and estimate the share of farm and non-farm income in the total household income, and analyze the determinants of non-farm income diversification of farm households in the study area.

\section{Methodology}

\subsection{Description of the study area}

Peshawar district is the capital of Khyber Pakhtunkhwa province, located at the north-west end of Pakistan. The total reported area of the district is about 1,257 square $\mathrm{km}$, having over 236 rural villages. The rural population is slightly higher as $1,898,478$ (51.5 percent) while the urban population is about 1,787,157 (48.5 percent) (Alhasan, 2015). The rural economy of the district is agricultural based with majority of the rural households engaged in crop farming and livestock rearing along with some non-agriculture activities. The district is famous for producing both food and cash crops. The main food crops are wheat, maize and barley while the main cash crop is sugarcane. The principal fruits are plum, peach, pear, apricot, watermelon, muskmelon, apple, guava, mango, persimmon and loquat. Vegetables grown in the district are turnip, carrot, spinach, tomato, cauliflower, cabbage, peas, radish and ladyfinger (IRM, 2012). Over the last 13 years, rapid urbanization and unplanned construction have gobbled up 3,307 acres of agriculture land in district Peshawar. The total agriculture land in the district was 109,883 acres in 2001-02, which shrank to 106,576 acres in 2013-14 (Ali, 2014).

Table 1. Village-wise Land Utilization and Population

\begin{tabular}{cccccc}
\hline Villages & $\begin{array}{c}\text { Geographical Area } \\
\text { (Acres) }\end{array}$ & $\begin{array}{c}\text { Cultivated Area } \\
\text { (Acres) }\end{array}$ & $\begin{array}{c}\text { Distance to Main } \\
\text { Peshawar City }(\mathrm{km})\end{array}$ & $\begin{array}{c}\text { Estimated } \\
\text { Population }\end{array}$ & $\begin{array}{c}\text { No. of registered } \\
\text { farm families }\end{array}$ \\
\hline Lala & 1529 & 1123 & 9 & 26330 & 156 \\
Jogian & 1746 & 1064 & 10 & 30468 & 164 \\
Urmar Miana & 3419 & 2995 & 16 & 41500 & 648 \\
Urmar Bala & 2064 & 1617 & 17 & 36993 & 384 \\
\hline
\end{tabular}

Source: Office of Agricultural Extension Tarnab, Peshawar, 2015

DE GRUYTER OPEN 
Kanwal N., Khan M.A., Zheng Z. (2016).

Analyzing the determinants of non-farm income diversification

of farm households in Peshawar district of Pakistan

\subsection{Research site}

The study was undertaken in four purposively selected villages namely; Lala, Jogian, Urmar Miana and Urmar Bala of Peshawar district, considering the fact that many empirical studies have found that relative location of rural households to near town/city has significant effect on non-farm employment participation decision of households. The following figure shows the geographical and demographic features of all the four villages:

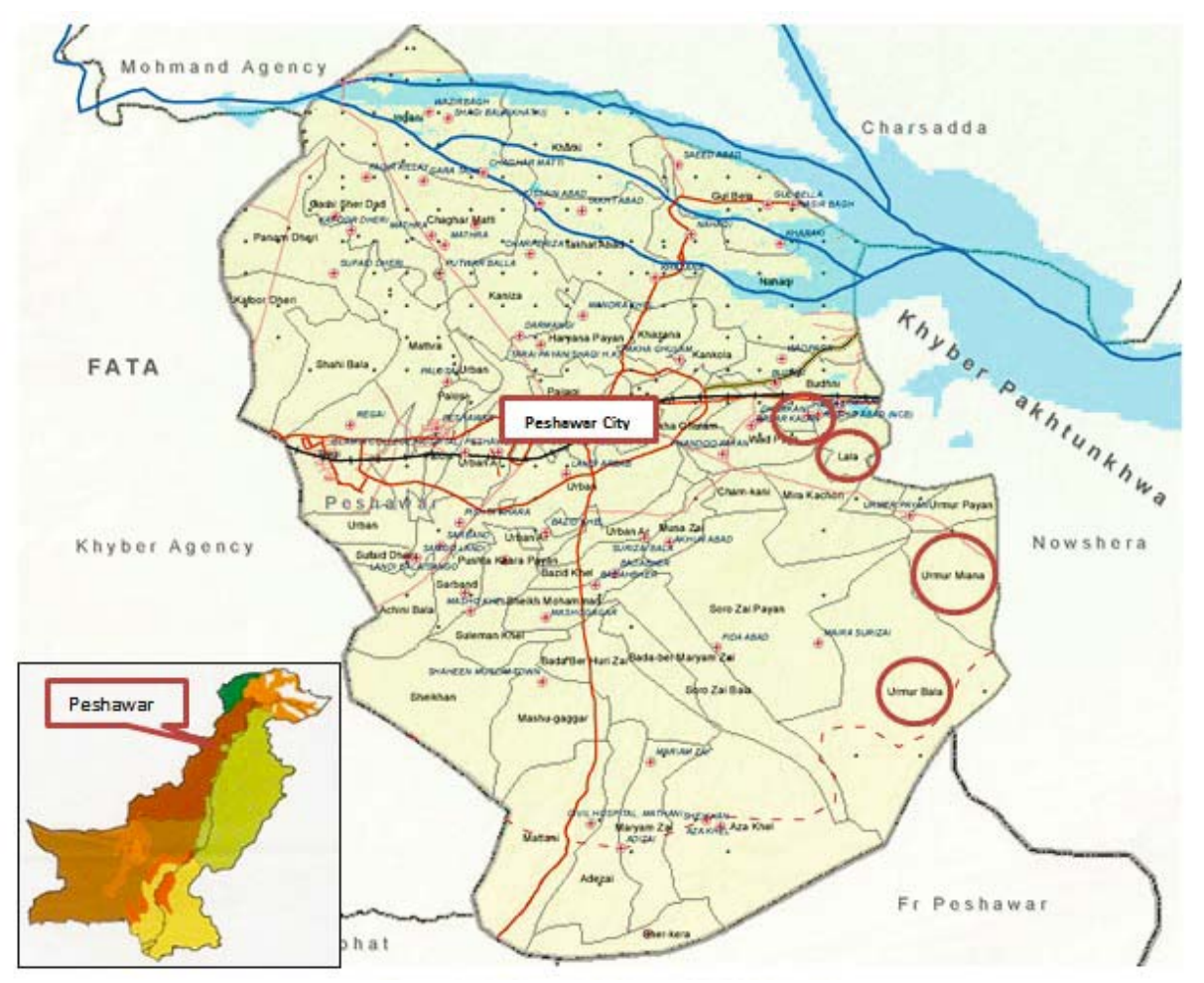

Figure 1. Map showing Peshawar district of Pakistan

Moreover, by using the comparative analysis approach, features of all the four villages (such as infra-structure, socioeconomic indicators, transport and communication facilities, and allied markets for various commodities) were compared to understand the pattern and structure of rural non-farm employment which were helpful in generalizing the results of the study

\subsection{Unit of analysis and sample size}

There is mounting evidence in the literature (Okali, et al., 2001; DFID, 2004; Sarah, 2012; Teshome \& Edriss, 2013) that the income from household members' participation in non-farm activities contributes significantly to farm households' welfare. For the present study, the farm 
Kanwal N., Khan M.A., Zheng Z. (2016).

household was taken as a unit of analysis and data were collected at household level from the head of households. However, multistage sampling technique was employed in selecting the representative farm households used for this study. Lists of farm households (from the selected villages) registered with local Agricultural Extension Office were obtained. Households having less than 12.5 acre $^{1}$ farm were separated and distributed proportionally in all the four villages. Several studies reveal that marginal and small farmers are highly devoted to non-farm employment activities to fulfill their needs, therefore, this study has also focused household with small farms. Finally, the total sample of 196 farm households was developed by using the following formula:

$$
n^{2}=\frac{\mathrm{K}^{2} \beta^{2} \mathrm{~N}}{\mathrm{Ne}^{2}+\mathrm{K}^{2} \beta^{2}}
$$

where: $n^{2}=$ sample size, $K=$ maximum accepted error (its maximum value is 3 and $1 / 3^{\text {rd }}$ of the sample variance), $\beta^{2}=$ variance, $e=$ error term, and $\mathrm{N}=$ total size of population.

\subsection{Data collection}

In this survey both primary and secondary data were collected from different sources to provide a more comprehensive picture of each aspect of the study. A structured questionnaire was designed to collect the primary data, in which both quantitative and qualitative data were gathered from the sample respondents through face to face interviews during the months of July to September, 2015. The questionnaire included information of demographic characteristic, socio-economic characteristics, household participation in farm and non-farm activities and the associated gross incomes generated in cash (and kind payments where applicable) in the survey year (12 months preceding time of data collection). Information on productive assets owned and household expenditure were also obtained. While secondary data were collected from available reports and records of the agriculture and rural development offices in the study area, published journals from websites and unpublished literatures from different sources.

\subsection{Methods of data analysis}

The Mean of Income Shares approach was used to estimate the income shares obtained by the farm households in the study area. This approach estimates the shares of incomes at the individual household level (Davis et al., 2010) by finding the share of each income source in the total household income for each household. The general Mean of Income Shares formula is given as:

\footnotetext{
${ }^{1}$ According to Pakistan Land Reform Regulations 1972, a marginal farmer is defined as a household which manages land less than 5 acres while a small farmer manages greater than or equal to 5 acres but less than 12.5 acres (Pakistan Agricultural Census Report, 2010).
}

\section{DE GRUYTER OPEN}

Timisoara Journal of Economics and Business | ISSN: 2286-0991 | www.tjeb.ro Year 2016 | Volume 9 | Issue 1 | Pages: 33 - 48 
Kanwal N., Khan M.A., Zheng Z. (2016).

$$
M S_{i}=\frac{\sum_{h=1}^{n} \frac{y_{i h}}{Y_{h}}}{n}
$$

Where; $i=$ the income source, $y=$ income from particular activity, $Y=$ total income, $h=$ the household, $n=$ the number of households. Equation (1) is applied in this study as the sum of Total Household Income (THI) is given as:

$$
T H I=\sum_{j=1}^{7} Y_{j}
$$

Where; $T H I=$ total household income, thus income coming from all sources $j j=1,2,3,4 \ldots 8$, farm and non-farm income.

However,

(a) The mean Share of Farm Income (SFI) is given as:

$$
S F I=\sum\left(\frac{\sum \frac{g c i}{t h i}}{n}+\frac{\sum \frac{f c i}{t h i}}{n}+\frac{\sum \frac{v c i}{t h i}}{n}+\frac{\sum \frac{l i v s t i}{t h i}}{n}\right)
$$

(b) The mean Share of Non-farm Income (SNFI) is given as:

$$
\mathrm{SNFI}=\sum\left(\frac{\sum \frac{n f w i}{t h i}}{n}+\frac{\sum \frac{\mathrm{sei}}{t h i}}{n}+\frac{\sum \frac{\mathrm{othersi}}{t h i}}{n}\right)
$$

Where; sfi=share of farm income, snfi=share of non-farm income, thi=total household income, $g c i=$ grain crop income, $f c i=$ fruit crop income, $v c i=$ vegetable crop income, livsti=livestock income, nfwi=non-farm wage income, sei=self-employment income, othersi=other sources income, $n=$ number of households.

\subsection{Ordinary Least Squares (OLS) model}

The determining factors of non-farm income diversification such as farm size, household size, livestock holding, proximity to the nearest city, access to credit, age and education etc. have been found by numerous empirical studies. Therefore, for the present study, the same determinants of non-farm income diversification were tested in the study area. The popular econometric techniques used to analyze such determinants are logistic models e.g. Logit \& 
Kanwal N., Khan M.A., Zheng Z. (2016).

Probit (Giorgi 2001; Janowski \& Bleahu 2001; Davis et al. 2010). By its very nature these models give probability of the existence or absence of a feature. However, in these models dependent variable is least affected by the magnitude of the independent variables. Another problem associated with these models is that the signs of parameters cannot be confidently interpreted (Gujrati, 2004). On the other hand, in the OLS analysis the dependent variable is affected by the magnitude of the independent variable and thus can provide more precise and consistent results. Besides that this technique, by the virtue of its BLUE properties, is free of both drawbacks of the logistic models. However, it should be cared that the results of OLS's models are valid when the basic assumptions of the model like non-existence of multicollinearity, autocorrelation and heteroscedasticity are not violated. In this study, the OLS technique is applied to analyze the determinants of non-farm income diversification. Econometrically:

$$
Y=\beta_{0} \cdot \beta_{1} X_{1}+\beta_{2} X_{2}+\beta_{3} X_{3}+\beta_{4} X_{4}+\beta_{5} X_{5}+\beta_{6} X_{6}+\beta_{7} X_{7}+\beta_{8} X_{8}+e
$$

where:

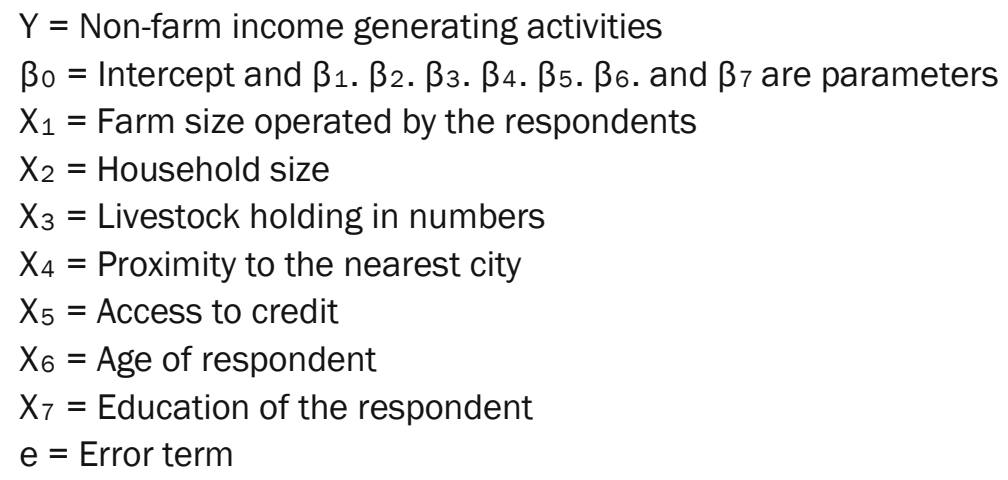

However, the respective model was estimated by using MS-Excel and SPSS statistical package 2012.

\section{Results and Discussions}

\subsection{Socioeconomic characteristics of the households}

The socioeconomic characteristics of the households are presented in Table 2.

The result of the analysis showed that male headed households (96.4\%) dominated in the study area. Majority $(88.3 \%)$ of the respondents were married with about $54.1 \%$ of the respondents having between $7-10$ members per household. The average household size in the study area was 9 . The relatively large household size can be linked to the need for family labor in the area as of at least 3 members of each household on average were involved in income generating activities. Age is an important socioeconomic characteristic as strength for required labor reduces with age. The modal age of the household heads in the study area was between 50 -

\section{DE GRUYTER OPEN}

Timisoara Journal of Economics and Business | ISSN: 2286-0991 | www.tjeb.ro Year 2016 | Volume 9 | Issue 1 | Pages: 33 - 48 
Kanwal N., Khan M.A., Zheng Z. (2016).

60 years. The implication of this is that majority of the household heads in the study area were becoming old and less active which could affect their productivity and income level. Majority of the respondents (60.7\%) had no formal education, while $24.4 \%$ had primary education. Farming was the primary occupation and major source of income of the household heads. The respondents who were predominantly farmers had a modal farm size of about $1.5-2$ acres and the average farm size was 1.89 acres which indicates that most of the farmers own smaller area of land.

Table 2. Descriptive Statistics of Households Socioeconomic Variables

\begin{tabular}{|c|c|c|c|}
\hline Characteristics & Description & Frequency & Percentage \\
\hline Gender of the household heads & $\begin{array}{l}\text { Female } \\
\text { Male }\end{array}$ & $\begin{array}{c}7 \\
189\end{array}$ & $\begin{array}{c}3.6 \\
96.4\end{array}$ \\
\hline Marital status of the household heads & $\begin{array}{c}\text { Married } \\
\text { Unmarried } \\
\text { Widowed/Separated }\end{array}$ & $\begin{array}{c}173 \\
14 \\
9\end{array}$ & $\begin{array}{l}88.3 \\
7.1 \\
4.6\end{array}$ \\
\hline Age of household heads & $\begin{array}{c}28-38 \\
39-49 \\
50-60 \\
61-71 \\
>71\end{array}$ & $\begin{array}{l}32 \\
45 \\
79 \\
28 \\
12\end{array}$ & $\begin{array}{c}16.4 \\
22.9 \\
40.3 \\
14.2 \\
6.2\end{array}$ \\
\hline Formal education of the household heads & $\begin{array}{l}\text { No formal education } \\
\text { Primary education } \\
\text { Secondary education } \\
\text { Tertiary education }\end{array}$ & $\begin{array}{c}119 \\
48 \\
25 \\
4\end{array}$ & $\begin{array}{c}60.7 \\
24.4 \\
12.8 \\
2.1\end{array}$ \\
\hline Farm size (Acres) & $\begin{array}{l}0.5-1 \\
1.5-2 \\
2.5-3 \\
>3.5\end{array}$ & $\begin{array}{l}52 \\
93 \\
35 \\
16\end{array}$ & $\begin{array}{l}26.5 \\
47.4 \\
17.9 \\
8.2\end{array}$ \\
\hline Household size & $\begin{array}{c}3-6 \\
7-10 \\
11-14 \\
15-18\end{array}$ & $\begin{array}{c}57 \\
106 \\
24 \\
9\end{array}$ & $\begin{array}{c}29.0 \\
54.1 \\
12.3 \\
4.6\end{array}$ \\
\hline $\begin{array}{l}\text { Household member involved in income } \\
\text { activites }\end{array}$ & $\begin{array}{l}1-3 \\
4-6 \\
7-9\end{array}$ & $\begin{array}{c}102 \\
85 \\
9\end{array}$ & $\begin{array}{c}52.0 \\
43.5 \\
4.5\end{array}$ \\
\hline
\end{tabular}

Source: Survey Data, 2015

\subsection{Farm households' participation rate in various income activities}

Table 3 shows household's participation rate in the different income sources.

The data indicates that under farm activities, majority (32.54\%) of the sample households was involved in vegetable farming followed by $26.19 \%$ in grain farming, $23.05 \%$ in fruit farming and 
Kanwal N., Khan M.A., Zheng Z. (2016).

$18.22 \%$ in livestock rearing. This indicates that farm households in the study area had diversified income sources within agricultural sector. However, the households were also equally involved in diversified non-farm income sources. Majority (56.57\%) of the households was involved in self-employment income generating activities (such as shop keeping, petty trading, handicrafts, food processing, driving, private micro-entrepreneurship etc.) followed by $30.65 \%$ in non-farm wages (construction, manufacturing and sales workers etc.) and $12.78 \%$ in other activities (such as collecting rents and regular salaries etc.). This illustrates that farm households in the study area have been actively participating in multiple income generating activities, therefore, it is important to understand the sample households in terms of their occupational preferences.

Table 3. Farm Households' Participation Rate in Various Income Activities

\begin{tabular}{lc}
\hline Income Activities & $\begin{array}{c}\text { Participation } \\
\text { Rate }(\%)\end{array}$ \\
\hline Farm Activities & 100.00 \\
- Grain Crops & 26.19 \\
- Fruit Crops & 23.05 \\
- Vegetable Crops & 32.54 \\
- Livestock & 18.22 \\
Non-farm Activities & 100.00 \\
- Non-farm wages & 30.65 \\
- Self-employment income & 56.57 \\
- Others & 12.78 \\
\hline
\end{tabular}

Source: Survey Data, 2015.

\subsection{Mean share of farm and non-farm income in the total household income}

The mean share of farm and non-farm income in the total household income is explained in Table 4.

Mean Share of Farm Income: In this study, we divided the farm income sources into four categories i.e. income from grain crops, income from fruit crops, income from vegetable crops and income from livestock. During the survey, it was found that the most common crops grown in all the four villages were maize and wheat along with seasonal vegetables (such as tomato, potato, spinach, cauliflower, turnip, lady finger, garlic and onion etc.) for economic as well as household's own consumption. However, livestock rearing (such as buffalos, cows and goats) was found as a vital source of income in Lala and Jogian villages but in Urmar Miana and Urmar Bala, livestock was kept for households' personal use only. On the other hand, orchards of plum, pear and peach were the main fruit crops grown in Urmar Miana and Urmar Bala villages and used as a prime source of income of farm households. The results, in Table-3 revealed that the grain crops income source recorded the highest income share of $18.70 \%$ followed by 
Kanwal N., Khan M.A., Zheng Z. (2016).

vegetable crops income share of $15.08 \%$, fruit crops income share of $13.22 \%$, and livestock share had $12.05 \%$ in the total household annual income. Thus, the total farm income share represents $59.05 \%$ of total household annual income. However, the diversity in the farm income is due to variation in geographical location and natural resources available to the households in their villages.

Table 4. Mean Share of Farm and Non-farm income in the Total Household Income

\begin{tabular}{lc}
\hline Income sources & Mean income share (\%) \\
\hline Farm Activities & 100.00 \\
- Grain Crops & 18.70 \\
- Fruit Crops & 13.22 \\
- Vegetable Crops & 15.08 \\
- Livestock & 12.05 \\
Non-farm Activities & 40.95 \\
- Non-farm wages & 13.62 \\
- Self-employment income & 20.15 \\
- Others & 7.18 \\
\hline Total Household Income & 100.00
\end{tabular}

Source: Survey Data, 2015.

Mean Share of Non-farm Income: During the survey, it was noticed that most households had one or more additional sources of income other than farming, therefore, we divided the nonfarm income into three sources i.e. income from non-farm wage, income from self-employment, and income from other sources. The results in Table-3 revealed that the self-employment income share (20.15\%) represents the largest share in the non-farm income share category. Non-farm wage income share follows with $13.62 \%$, while other income source share recorded $7.18 \%$ respectively. In total, the share of non-farm income in total household annual income was found to be $40.95 \%$, lower than the share of income generated from the farm sector by farm households.

The result demonstrates that the farm sector continues to be vital to farm households in the study area, since a major portion of their income is derived from activities in the sector. However, income from farming was no longer sustaining the households so the households had fairly diversified to other sources of income outside their farms. It is now well recognized that rural economy is not purely agricultural and that farm households across the study area earn an increasing share of their income from non-farm activities. 
Kanwal N., Khan M.A., Zheng Z. (2016).

Analyzing the determinants of non-farm income diversification

of farm households in Peshawar district of Pakistan

\subsection{Determinants of non-farm income diversification}

The result of the OLS regression estimates of the determinants of non-farm income diversification is presented in Table 5 given below:

Table 5. Estimated Non-Farm Income Functions

\begin{tabular}{lccccc}
\hline \multicolumn{1}{c}{ Variable $\left(\mathrm{X}_{\mathrm{i}}\right)$} & $\begin{array}{c}\text { Unit of } \\
\text { Measurement }\end{array}$ & $\begin{array}{c}\text { Estimated } \\
\text { Coefficient }(\beta)\end{array}$ & $\begin{array}{c}\text { Standard } \\
\text { Error }(\mathrm{e})\end{array}$ & t-ratio & p-value \\
\hline Farm size cultivated $\left(\mathrm{X}_{1}\right)$ & Acre & $0.4370 * *$ & 0.050127 & 6.843 & 0.000 \\
Household size $\left(\mathrm{X}_{2}\right)$ & Number & $0.31589 * *$ & 0.7535 & 3.611 & 0.001 \\
Livestock holding $\left(\mathrm{X}_{3}\right)$ & Number & $-0.0054 * *$ & 0.0197 & -3.145 & 0.001 \\
Proximity to the nearest city $\left(\mathrm{X}_{4}\right)$ & Kilometer & $0.0610 * *$ & 0.0190 & 3.210 & 0.000 \\
Ccess to credit $\left(\mathrm{X}_{5}\right)$ & $\mathrm{Rs}$ & 1.8420 & 0.1820 & 1.582 & 0.117 \\
Age of respondents $\left(\mathrm{X}_{6}\right)$ & Year & $-0.5350 * *$ & 0.1240 & -3.941 & 0.000 \\
Education of the respondent $\left(\mathrm{X}_{7}\right)$ & Year & $0.1894 * *$ & 0.5440 & 3.341 & 0.001 \\
Constant & - & $1.3951 * *$ & 0.411 & 3.502 & 0.001 \\
\hline $\mathrm{F}=41.20, \mathrm{R}^{2}=0.795$, Adjusted $\mathrm{R}^{2}=0.775$, Durbin Watson=1.794, **Significant at 1\% & &
\end{tabular}

Source: Survey Data, 2015.

The F-statistic is large and significant and the values of $\mathrm{R}^{2}$ and $\mathrm{R}^{2}$ adjusted are high for this cross sectional data which proves the model as a whole is statistically significant. The value of $\mathrm{R}^{2}$ is 0.795 which implies that $79.50 \%$ of the variation in the dependent variable $\mathrm{Y}$ is explained by the variations in the independent variables included in the model. While $\mathrm{R}^{2}$ adjusted measures the proportion of the variance in the dependent variable that is explained by the variation in the independent variables. $\mathrm{R}^{2}$ adjusted in this case shows that $0.775 \%$ of the variation in the dependent variable is explained by the independent variables. The results of individual variables show that Age and Livestock holding were negatively related to non-farm income diversification, while the Farm size, Household size, Education level of household heads and Proximity to the nearest city positively impacted the dependent variable. The only variable found to be insignificant was Access to Credit. All the coefficients carry correct signs giving us considerable confidence in the results. The findings of individual explanatory variables are interpreted in the proceeding paragraphs.

Farm Size was positively associated with non-farm income diversification. Land was a very important resource in the study area and due to the fragmented nature of land holdings the sample households had smaller farms for cultivation which pushed them to non-farm income activities. Thus, the positive sign of the variable is correct according to economic theory and findings of the research previously done on the same topic. Therefore, we accept the hypothesis of correlation between farm size and non-farm income diversification. The results indicate that decrease in the farm size will definitely increase non-farm income activities. 
Kanwal N., Khan M.A., Zheng Z. (2016).

Household size was significant and positively related with the non-farm income diversification. The values reveal that farm household with large members, on average; devote more time to non-farm activities. This may be due to the fact that the increase in farm household size means an increase in family labor. On the other hand, larger farm households diversify more as much of their income is geared towards consumption and for household needs. This attests the hypothesis of positive correlation between household size and non-farm income diversification.

Livestock was negatively correlated with non-farm income diversification. The ratio is also significant and results are also in accordance with economic theory. Livestock is among the productive assets which are mostly agricultural and can be seen as proxies for socio-economic group or wealth. Members of farm households which are relatively well-off are likely to participate in non-farm jobs but when they do, they spend relatively less time in this activity.

Proximity to the nearest city was found significant and positively correlated with non-farm income diversification. This is because of greater business, wage work, and public/private job opportunities available to the people. Hence, proximity to local markets increased the likelihood of non-farm employment participation.

Credit which is another indicator of financial status in the model is not found to affect the participation decision.

Age of the heads of households had significant and negative relationship with non-farm income diversification, which meant that as the age of farmer increases, his willingness or ability to work non-farm decreases. This is because they lack the physical strength and financial resources to add on to their farm or non-farm activities since a majority of these activities are found to be labor intensive. However, the younger household members were highly devoted to non-farm employment activities and they might support their heads in terms of financial support.

Education level of the household heads was significant and positively influenced income diversification among farm households in the study area. Thus, having some educational level attainment facilitates entry into high paying jobs such as public and private services, businesses, masters of transport stations, as well as improving farmers understanding of farming practices and related issues as observed by this study.

\section{CONCLUSIONS AND RECOMMENDATIONS}

The empirical analysis of the household income revealed that the estimated shares of the income sources in the household's total income have justified the importance of farm as well as non-farm income practiced by farm households. Even though agriculture is the dominant source 
Kanwal N., Khan M.A., Zheng Z. (2016).

of income for farm household, 40.95 percent of the contribution of non-farm sources clearly points to the fact that participation in the non-farm employment activities is extremely important towards increasing the absolute income of small farmers. Non-farm income diversification is hence crucial for sustaining livelihoods and an integral dimension for strengthening rural economies. The result reveals that small size of landholdings and lower farm profits tend to push farm households out of agriculture, however, pull factors such as self-employment and public/private services are dominantly found to be the most important drivers of participation in non-farm employment because of proximity to the nearest city. Households' decision to participate in non-farm work is principally to increase their earnings and not on the intention of risk reduction as opposed to households whose decision to diversify is due to push factors. This is a clear indication that farming is not a sufficient source of revenue for the farm households in the study area.

From a policy perspective, the findings suggest that, although most households participate in the farm sector, rural development policies aimed at poverty reduction should focus equally on both the farm and the non-farm sectors. Farming as a primary source of income has failed to guarantee sufficient livelihood for most farming households in developing countries and agricultural development policies have largely produced little improvement, especially in Pakistan. Non-farm activities have been meeting the gap by directly increasing households' income and providing cash that is invested in farm inputs to increase agricultural production and also raising their living standards. The concern therefore should be to implement policies that will impact positively on both sectors for overall improvement in rural life. Given the complementarities between non-farm and farm activities and the fact that both sectors actually face similar constraints, application of appropriate policy programs that can serve both sectors is recommended. For instance, removing credit market imperfections and creation of accessible credit schemes can facilitate the establishment of non-farm businesses and promote agricultural development simultaneously. Likewise, provision of physical infrastructure can reduce transaction costs in both sectors and increase overall employment opportunities.

\section{References}

Ahmed, F. (2012). Exploring the Linkages between Rural Incomes and Non-farm Activities. Journal of Agriculture \& Social Sciences, 8(3), 81-86.

Alhasan, (2015). Pakistan Emergency Situation Analysis - District Peshawar. Report available at: http://reliefweb.int/report/pakistan/pakistan-emergency-situation-analysisdistrict-peshawar-april-2015

Ali, Z. (2014). Peshawar Loses Vast Agricultural Land to Urbanization. DAWN. Retrieved on 24 August, 2015 from http://www.dawn.com/news/1140287

DE GRUYTER OPEN
Timisoara Journal of Economics and Business | ISSN: 2286-0991 | www.tjeb.ro

Year 2016 | Volume 9 | Issue 1 | Pages: 33 - 48 
Kanwal N., Khan M.A., Zheng Z. (2016).

Analyzing the determinants of non-farm income diversification

of farm households in Peshawar district of Pakistan

Barrett, C.B., \& Reardon, T. (2000). Asset, Activity and Income Diversification among Africa Agriculturalists: Some Practical Issues. In Income Diversification and Livelihoods in Rural Africa: Cause and Consequence of Change. Special edition of Food Policy.

Barrett, C.B., Reardon, T., \& Webb, P. (2001). Nonfarm Income Diversification and Household Livelihood Strategies in Rural Africa: Concepts, Dynamics and Policy Implications. Food Policy, 26, 315-331.

Chaplin, H., Davidova, S., \& Gorton, M. (2004). Agricultural Adjustment and the Diversification of Farm Households and Corporate Farms in Central Europe. Journal of Rural Studies, 20, 61-77.

Chaudhry, I.S., Malik, S., \& Ashraf, M. (2006). Rural Poverty in Pakistan Same Related Concepts, Issues and Empirical Analysis. Pakistan Economic and Social Review, 42(2), 259-276.

Davis, B., Winters, P., Carletto, G., Covarrubias, K., Quinones, E.J., Zezza, A., Stamoulis, K., Azzarri, C., \& Digiuseppe, S. (2010). A Cross Country Comparison of Rural Income Generating Activities. World Development, 38(1), 48-63.

DFID - Department for International Development, (2004). Rural Urban Development Case Study - Nigeria. Oxford Policy Management, United Kingdom.

Dimova, R., \& Sen K. (2010). Is Household Income Diversification a Means of Survival or a Means of Accumulation? Panel Data Evidence from Tanzania. Working Paper, 122, 1-34. Brooks World Poverty Institute, Manchester.

Ellis, F. (2000). Rural Livelihoods and Diversity in Developing Countries. Department for International Development. Oxford University Press, Oxford.

Giorgi, M. (2001). Rural Non-farm Economy in Georgia: A Pilot Research Report. Natural Resources Institute Report. No. 2677. Department for International Development (DFID)/World Bank Collaborative Program for Rural Development.

Gujrati, D.N. (2004). Basic Econometrics. Int'I Ed. McGraw Hill Publishers, New York.

IFAD - International Fund for Agricultural Development, (2011). Rural Poverty Report. Available at: http://www.ifad.org/rpr2011/report/e/overview.pdf

IRM - Institute of Rural Management, (2012). Labour Market Survey. Exploring \& Economic Opportunity through Vocational Skills Training, District Peshawar (Khyber Pakhtunkhwa). Available at: http://www.irm.edu.pk/wpcontent/uploads/2012/05/Labour-Market-Study-Peshawar-IRM-2013.pdf

Janowski, M., \& Bleahu, A. (2001). Factors Affecting Household-level Involvement in Rural Non-farm Economic Activities in Two Communities in Dolj and Brasovjudete, Romania. Paper presented at the workshop "Rural non-farm employment and development in transition economies. University of Greenwich, London.

Korir, L.K., Legat, K.J., \& Njehia, B.K. (2011). The Role of Non-farm Investments in Agricultural Risk Management in Kenya. International Journal of Economic Theory, $3(2), 62-68$.

Lay, J., \& Schuler, D. (2008). Income Diversification and Poverty in a Growing Agricultural Economy: The Case of Ghana. Proceedings of the German Development Economics Conference, Zurich 39, 1-39.

Maqbool, N. (2014). The Man Who Championed the Cause for Poverty Alleviation: Remembering Dr. Mahbubul Haq. The New International. Retrieved on March, 9 2015 from http://www.thenews.com.pk/Todays-News-2-262426-The-man-whochampioned-the-cause-for-poverty-alleviation 
Kanwal N., Khan M.A., Zheng Z. (2016).

Analyzing the determinants of non-farm income diversification

of farm households in Peshawar district of Pakistan

Minot, N., Epprecht, M., Anh, T.T.T., \& Trung, L.Q. (2006). Income Diversification and Poverty in the Northern Uplands of Vietnam. Research Report, 145, 1-111. International Food Policy Research Institute, Washington, D.C.

Okali, D., Okpara, E., \& Olawoye, J. (2001). Rural-Urban Interactions and Livelihood Strategies, The Case of Aba and its Region, Southeastern Nigeria. Working Paper 4. International Institute for Environment and Development (IIED) 3 Endsleigh Street, London WC1H ODD, United Kingdom.

Pakistan Agricultural Census Report, (2010). Agricultural Census Organization, Statistics Division, Government of Pakistan. Report available at: http://www.fao.org/fileadmin/templates/ess/ess_test_folder/World_Census_Agric ulture/Country_info_2010/Reports/Reports_5/PAK_ENG_REP_2010.p.pdf

Pakistan Economic Survey, (2013-14). Agriculture - Chapter 2. Ministry of Finance, Government of Pakistan. Available at: http://www.finance.gov.pk/survey/chapters_14/02_Agriculture.pdf

Readon, T., Stamoulis, R., Cruz, M.E., Balican, A., Berdegue, J.A, \& Banks B. (1998). Rural Non-farm Income in Developing Countries, special chapter in FAO. The State of Food and Agriculture 1998. Food and Agriculture Organization of the United Nations, Rome.

Ronning, L., \& Kolvereid, L. (2006). Income Diversification in Norwegian Farm Households, Reassessing Pluriactivity. International Small Business Journal, 24(4), 405-419.

Sarah, A. (2012). Determinants of rural household income diversification in Senegal and Kenya. In : 6èmes Journées de recherches en sciences sociales SFER-INRA-CIRAD. SFER, INRA, CIRAD, Toulouse School of Economics. Paris: SFER, 18.

Teshome, B., \& Edriss, A. (2013). Determinants and Patterns of Income Diversification among Smallholder Farmers in Akaki District, Ethiopia. Journal of Research in Economics and International Finance, 2(4), 68-78. 